\title{
IMPACT OF SMARTPHONE USE AND FAMILY SUPERVISION IN SLEMAN, YOGYAKARTA
}

\author{
Nur Alvira Pascawati, Fajarina Lathu Asmarani \\ Faculty of Health Sciences, Universitas Respati Yogyakarta
}

\begin{abstract}
Background: The adoption of the smartphone by young people has been a global phenomenon in recent years. The smartphone has lead to changed dynamics in the family, with issues of safety and surveillance. Smartphone offers convenience in life, but it poses some negative effects. The National Board of Population and Family Planning (BKKBN) has implemented the Adolescents Family Development (BKR) program and the Information and Counseling Center for Youth (PIK-R) program with the aim to enhance parent-child communication and peer social interaction. This study aimed to examine impact of smartphone use and family supervision in Sleman, Yogyakarta.

Subjects and Method: This was a cross sectional study conducted in Sleman district, Yogyakarta. A sample of 120 families with adolescents was selected for this study. The dependent variables were learning concentration, self confidence social interaction, parental supervision. The independent variable was BKR/PIK-R program and smartphone use. The data were collected by questionnaire and tested by chi square.

Results: $>40 \%$ of adolescents who used smartphone lost learning concentration, $>50 \%$ considered smartphone as a friend in loneliness and a tool to enhance self confidence and socialization, $>70 \%$ felt comfortable in social interaction with peer, $>80 \%$ were addicted to smartphone use. BKR/PIK-R program made the parents more active in communication with and supervision of their children.
\end{abstract}

Conclusion: BKR/PIK-R program make the parents more active in supervising their children.

Keywords: smartphone, supervision, family, information, counseling center, adolescent

Correspondence:

Nur Alvira Pascawati. Faculty of Health Sciences, Universitas Respati Yogyakarta.

Email: irha011185@yahoo.com. Mobile:+628176616928.

The $5^{\text {th }}$ International Conference on Public Health

Best Western Premier Hotel, Solo, Indonesia, February 13-14, 2019 | 194

https://doi.org/10.26911/theicph.2019.02.30 